\title{
Analisis Pengaruh Harga, Kemudahan Penggunaan, dan Ulasan Konsumen Daring Terhadap Keputusan Pembelian Pada Marketplace Shopee
}

\author{
Mita \\ Universitas Sanata Dharma, Yogyakarta \\ Fransisca Desiana Pranatasari \\ Universitas Sanata Dharma, Yogyakarta \\ Kristia \\ Universitas Sanata Dharma, Yogyakarta \\ Email:fr.desiana@usd.ac.id
}

\begin{abstract}
Abstrak
Pada tahun 2021 Shopee merupakan marketplace dengan traffic terbanyak kedua di Indonesia. Salah satu porsi segmen pelanggan terbesar Shopee berasal dari kalangan Generasi $\mathrm{Z}$ yang memiliki berbagai pertimbangan sehingga mereka yakin melakukan keputusan pembelian pada marketplace tersebut. Penelitian ini bertujuan untuk mengetahui: 1) pengaruh harga, kemudahan penggunaan, dan ulasan konsumen daring secara simultan terhadap keputusan pembelian, 2) pengaruh harga, kemudahan penggunaan, dan ulasan konsumen daring secara parsial terhadap keputusan pembelian. Teknik pengambilan sampel menggunakan purposive sampling dengan 100 orang responden yang memenuhi kriteria. Teknik analisis data dalam penelitian ini adalah analisis deskriptif, uji asumsi klasik, dan analisis regresi linier berganda dengan menggunakan program aplikasi SPSS Statistics 16. Hasil penelitian menunjukkan bahwa: 1) harga, kemudahan penggunaan, dan ulasan konsumen daring secara simultan berpengaruh terhadap keputusan pembelian, 2) harga secara parsial berpengaruh terhadap keputusan pembelian, 3) kemudahan penggunaan secara parsial tidak berpengaruh terhadap keputusan pembelian, 4) ulasan konsumen daring secara parsial berpengaruh terhadap keputusan pembelian.
\end{abstract}

Kata Kunci: harga, kemudahan penggunaan, ulasan konsumen daring, dan keputusan pembelian

\section{Pendahuluan}

Indonesia merupakan salah satu negara yang aktif memanfaatkan internet. Kemudahan akses internet memberikan dampak positif bagi berbagai macam kegiatan di Indonesia. Menurut We Are Social \& Hootsuite (2020:17) khusus negara Indonesia sendiri pada tahun 2020 jumlah pengguna internet yang aktif sebanyak 160.0 juta. Selain itu, kemajuan internet menjadi salah satu pemicu percepatan dalam dunia usaha. Dengan memanfaatkan internet, banyak pengusaha yang semakin dimudahkan untuk melakukan transaksi usaha mereka. Hal yang serupa pula dirasakan konsumen hingga kemajuan internet ini mempermudah konsumen dalam mengakses kebutuhan mereka melalui internet. Menurut laporan We Are Social \& Hootsuite (2020:65) disebutkan bahwa 88\% pengguna internet yang berusia 16 tahun hingga 64 tahun sudah melakukan pembelian produk dan layanan 


\section{Mita, Fransisca Desiana Pranatasari, Kristia}

secara daring. Konsumen melakukan pembelian mereka secara daring melalui suatu media yang kemudian disebut sebagai marketplace. Melalui marketplace inilah, pihak penjual yang menawarkan barang atau layanan mereka akan bertemu dan melakukan transaksi dengan pembeli. Dapat dikatakan bahwa marketplace ini bertindak sebagai platform peratara yang menghubungkan penjual dan pembeli.

Shopee adalah satu marketplace yang kini banyak digunakan sebagai media jual beli di Indonesia. Menurut We Are Social \& Hootsuite (2019:49) pada Q1 2019 aplikasi Shopee adalah aplikasi yang menempati ranking 2 teratas pengguna terbanyak di Indonesia. Menurut situs iprice.co.id (2020) pada Q2 2020 Shopee merupakan situs toko daring dengan jumlah pengunjung website terbanyak dengan total pengunjung web bulanan sebanyak 93.440.300. Hal ini akan semakin memberikan dampak apabila berimbas pada keputusan pembelian konsumen pada produk dan layanan yang ditawarkan penjual dalam marketplace Shopee. Keputusan pembelian itu sendiri merupakan suatu proses seseorang dalam membeli suatu barang atau layanan dengan merek tertentu sesuai dengan yang mereka inginkan. Sebelum menentukan keputusan untuk melakukan pembelian, tentunya pelanggan harus mempertimbangkan beberapa faktor seperti harga, kemudahan penggunaan, dan ulasan konsumen daring.

Dalam persespsi pengguna Shopee, harga yang ditawarkan dalam marketplace Shopee cenderung bersaing dibandingkan jika kita membeli langsung di toko luring, bahkan beberapa item terbilang cukup murah. Harga itu sendiri merupakan satu ukuran pengorbanan yang ditukarkan seseorang untuk mendapatkan hak penggunaan atas barang atau layanan yang diinginkannya.

Fitur yang ditawarkan dalam marketplace Shopee mudah digunakan oleh konsumen pemula. Davis (1989:320) mengatakan bahwa kemudahan penggunaan dapat diartikan sebagai salah satu tindakan saat pengguna suatu teknologi maupun sistem tertentu memiliki kepercayaan bahwa saat menggunakan teknologi maupun sistem tertentu dapat membantu pengguna untuk bebas dari suatu usaha yang sulit. Semakin mudah suatu sistem digunakan, maka akan semakin mempengaruhi konsumen untuk melakukan keputusan pembelian.

Pada marketplace Shopee terdapat ulasan konsumen daring sehingga sebelum konsumen memesan suatu produk maupun jasa, konsumen dapat melihat terlebih dahulu bagaimana komentar pembeli sebelumnya terhadap suatu produk maupun jasa yang ingin di beli. Ulasan konsumen daring dapat membantu konsumen dalam menentukan apakah akan melakukan pembelian atau tidak.

Beberapa literasi terdahulu (Istanti 2017; Atsila, Saroh, dan Krisdianto 2020; Wahyuningtyas dan Widiastuti 2015) menyatakan bahwa variabel harga, kemudahan penggunaan, dan ulasan konsumen daring berpengaruh terhadap keputusan pembelian. Di sisi lain terdapat inkonsistensi hasil penelitian terdahulu oleh (Rosdiana, Suharno, dan Kulsum 2020; Fandi, Arifin, dan Hufron 2019) yang mengatakan bahwa variabel harga dan kemudahan penggunaan tidak berpengaruh secara parsial terhadap keputusan pembelian.

Berdasarkan gap dan fenomena tersebut, maka rumusan masalah yang dapat terbangun yaitu apakah harga, kemudahan penggunaan, dan ulasan konsumen daring baik secara simultan maupun parsial berpengaruh terhadap keputusan pembelian. Hasil penelitian ini diharapkan dapat membantu perusahaan untuk mengatur strategi pemasaran khususnya dalam hal harga, kemudahan penggunaan, dan ulasan konsumen daring supaya dapat menarik keputusan pembelian pelanggan. 


\section{Landasan Teori dan Pengembangan Hipotesis}

\section{Harga}

Tjiptono (2019: 290) mengatakan bahwa harga merupakan satuan moneter maupun ukuran lainnya yang ditukarkan untuk mendapatkan hak kepemilikan maupun hak penggunaan atas suatu barang dan jasa. Penetapan harga adalah salah satu keputusan terpenting dalam pemasaran. Satu-satunya elemen pada bauran pemasaran yang dapat mendatangkan pendapatan bagi perusahaan yaitu harga, sedangkan elemen lainnya menimbulkan pengeluaran. Stanton 1998 (dalam Yusup 2011:27) memaparkan beberapa indikator harga sebagai berikut:

a. Keterjangkauan harga

b. Harga sesuai dengan kualitas produk

c. daya saing harga

d. Harga sesuai dengan manfaat

\section{Kemudahan Penggunaan}

Menurut Wahyuningtyas \& Widiastuti (2015:113) kemudahan penggunaan dapat mempengaruhi perilaku seseorang, jika seseorang memiliki persepsi yang sangat tinggi terhadap kemudahan dalam menggunakan suatu sistem maka tentunya tingkat penggunaan suatu sistem tersebut juga akan semakin tinggi. Jogiyanto (2007:115) mendefinisikan bahwa kemudahan penggunaan adalah sebesar apakah keyakinan pengguna saat menggunakan suatu teknologi maupun sistem tertentu akan terbebas dari usaha. Venkatesh dan Davis 2000 (dalam Sukron 2019:33) merumuskan dimensi kemudahan penggunaan, yaitu:

a. Gampang dimengerti dan jelas

b. Tidak membutuhkan usaha yang banyak untuk berinteraksi dengan sistem tersebut

c. Sistem dapat digunakan dengan gampang

d. Sistem sangat mudah dioperasikan berdasarkan kebutuhan dan keinginan pengguna

\section{Ulasan Konsumen Daring}

Khammash 2008:79 (dalam Febriana \& Yulianto 2018:4) mendefinisikan bahwa ulasan konsumen daring dapat diartikan sebagai suatu fasilitas yang disediakan oleh perusahaan agar dapat mempermudah pengguna untuk melihat bagaimana pendapat positif maupun negatif pengguna lain terhadap suatu produk maupun jasa yang ingin dibeli. Menurut Zhao, Xinyuan, Wang, Guo, dan Law 2015 (dalam Karmila, Suharyono, Nuralam 2019:204) ada enam syarat ulasan konsumen daring supaya dapat dikatakan efektif, yaitu:
a. Kegunaan Ulasan Konsumen Daring
b. Keahlian Peninjau
c. Ketepatan Waktu Ulasan Konsumen Daring
d. Jumlah Ulasan Konsumen Daring
e. Valensi Ulasan Konsumen Daring
f. Kelengkapan Ulasan Konsumen Daring

\section{Keputusan Pembelian}

Fatihudin dan Firmansyah (2019:57) mendefinisikan keputusan pembelian adalah membeli suatu merek tertentu yang diinginkan oleh konsumen. Ada 2 hal yang dapat menentukan keputusan pembelian yaitu situasi yang diinginkan oleh konsumen dan sikap orang lain terhadap produk maupun jasa tertentu. 
Kotler \& Keller (2009:184-190) mengatakan bahwa dalam proses keputusan pembelian konsumen terdapat beberapa tahap yaitu:

a. Pengenalan Masalah

b. Pencarian Informasi

c. Evaluasi Alternatif

d. Keputusan Pembelian

e. Perilaku Pascapembelian

\section{Pengembangan Hipotesis}

Harga merupakan faktor sensitif dibenak pelanggan, karena harga berkaitan langsung dengan pengorbanan tertentu yang harus mereka keluarkan. Dalam penelitian Fandi, Arifin \& Hufron (2019) terbukti bahwa seseorang melakukan pertimbangan perihal harga sebelum akhirnya melakukan keputusan pembelian. Beberapa pelanggan memiliki kecenderungan lebih menyukai harga yang murah daripada harga yang relatif mahal. Selain pertimbangan harga, dalam melakukan pembelian Wahyuningtyas \& Widiastuti (2015:113) juga mendapatkan hasil penelitian bahwa kemudahan penggunaan dapat mempengaruhi perilaku seseorang, jika seseorang memiliki persepsi yang sangat tinggi terhadap kemudahan dalam menggunakan suatu sistem maka tentunya tingkat penggunaan suatu sistem tersebut juga akan semakin tinggi. Jogiyanto (2007:115) mendefinisikan bahwa kemudahan penggunaan adalah sejauh mana pengguna yakin saat menggunakan suatu sistem akan terbebas dari usaha. Pelanggan cenderung lebih menginginkan sesuatu yang cepat, mudah dan tanpa banyak usaha yang harus mereka dikeluarkan untuk memperoleh suatu barang maupun jasa. Semakin mudah penggunaan suatu aplikasi tentunya, maka akan menarik pelanggan untuk melakukan keputusan pembelian. Salah satu aspek penting lainnya dikemukakan Khammash 2008:79 (dalam Febriana \& Yulianto 2018:4) bahwa ulasan konsumen daring (online consumer review) adalah suatu fasilitas yang disediakan oleh perusahaan agar dapat mempermudah pengguna untuk melihat bagaimana pendapat pengguna lain terhadap suatu produk maupun jasa yang ingin dibeli. Menurut Almana dan Mirza (2013:23) Ulasan konsumen daring dapat dimanfaatkan sebagai sarana bagi pelanggan dalam mencari maupun memperoleh suatu informasi yang nantinya dapat mempengaruhi keputusan pembelian. Ulasan yang diberikan oleh konsumen dapat mempengaruhi reputasi suatu produk dan jasa yang ditawarkan. Biasanya produk maupun jasa yang memiliki reputasi baik cenderung memiliki lebih banyak ulasan positif dibandingkan ulasan negatif, begitupun sebaliknya. Hal tersebut tentu saja akan mempengaruhi keputusan pembelian konsumen.

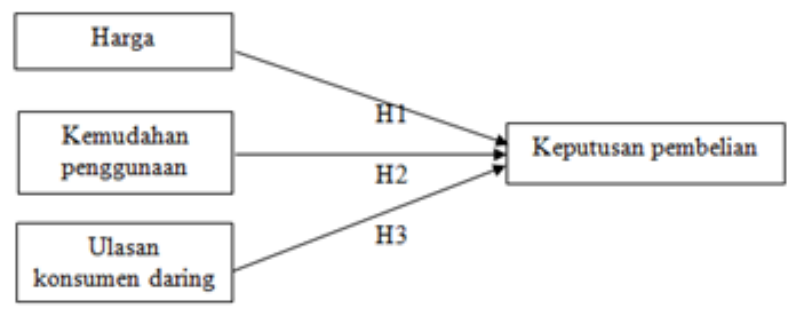

Gambar 1. Kerangka Konseptual Penelitian

$\boldsymbol{H}_{1}$ : Harga secara parsial berpengaruh terhadap keputusan pembelian.

$\boldsymbol{H}_{2}$ : Kemudahan penggunaan secara parsial berpengaruh terhadap keputusan pembelian.

$\boldsymbol{H}_{3}$ : Ulasan konsumen daring secara parsial berpengaruh terhadap keputusan pembelian. 


\section{Metode Penelitian}

Jenis penelitian ini adalah kuantitatif dengan metode survey. Lokasi penelitian dilaksanakan pada mahasiswa yang melakukan studinya di Yogyakarta dengan periode penelitian Oktober 2020 hingga Maret 2021. Seluruh mahasiswa aktif berlokasi di Yogyakarta inilah yang menjadi populasi dengan sampel 100 responden yang memenuhi kriteria penelitian. Instrumen penelitian ini adalah kuesioner yang kemudian menjadi data primer. Teknik pengambilan sample dilakukan dengan purposive sampling. Kriteria yang dipakai adalah mahaiswa aktif, sudah pernah melakukan pembelian pada marketplace Shopee minimal sebanyak 2 kali dalam setahun terakhir.

Tabel 1. Definisi Operasional

\begin{tabular}{|c|c|c|c|}
\hline No & Variabel & Definisi Operasional & Indikator \\
\hline 1 & Harga & $\begin{array}{l}\text { Harga adalah ukuran yang } \\
\text { dipakai untuk mendapatkan hak } \\
\text { kepemilikan atas barang yang } \\
\text { ditukarkan maupun sebagai hak } \\
\text { pengguaan atas barang dan jasa } \\
\text { yang ditawarkan dalam } \\
\text { marketplace Shopee. }\end{array}$ & $\begin{array}{l}\text { a. Keterjangkauan harga } \\
\text { b. Harga sesuai dengan kualitas } \\
\text { produk } \\
\text { c. daya saing harga } \\
\text { d. Harga sesuai dengan manfaat } \\
\text { (Stanton 1998 Yusup 2011:27) }\end{array}$ \\
\hline 2 & $\begin{array}{l}\text { Kemudahan } \\
\text { Penggunaan }\end{array}$ & $\begin{array}{l}\text { Kemudahan penggunaan adalah } \\
\text { tingkat keyakinan pengguna } \\
\text { marketplace Shopee ketika } \\
\text { menggunakan sistem dan } \\
\text { teknoogi yang ditawarkan } \\
\text { dilakukan tanpa merasa } \\
\text { terbebani dan membutuhkan } \\
\text { usaha ekstra. }\end{array}$ & $\begin{array}{l}\text { a. Gampang dimengerti dan jelas } \\
\text { b. Tidak membutuhkan usaha yang } \\
\text { banyak untuk berinteraksi dengan } \\
\text { sistem tersebut } \\
\text { c. Sistem dapat digunakan dengan } \\
\text { gampang } \\
\text { d. Sistem sangat mudah dioperasikan } \\
\text { berdasarkan kebutuhan dan keinginan } \\
\text { pengguna } \\
\text { (Venkatesh dan Davis } 2000 \text { dalam } \\
\text { Sukron 2019:33) }\end{array}$ \\
\hline 3 & $\begin{array}{l}\text { Ulasan } \\
\text { Konsumen } \\
\text { Daring }\end{array}$ & $\begin{array}{l}\text { Ulasan konsumen daring adalah } \\
\text { suatu fasilitas yang disediakan } \\
\text { oleh perusahaan dalam hal ini } \\
\text { marktplace Shopee agar dapat } \\
\text { mempermudah pengguna untuk } \\
\text { melihat bagaimana pendapat } \\
\text { positif maupun negatif } \\
\text { pengguna lain terhadap suatu } \\
\text { produk maupun jasa yang ingin } \\
\text { dibeli. }\end{array}$ & $\begin{array}{l}\text { a. Kegunaan Ulasan Konsumen } \\
\text { Daring } \\
\text { b. Keahlian Peninjau } \\
\text { c. Ketepatan Waktu Ulasan } \\
\text { Konsumen Daring } \\
\text { d. Jumlah Ulasan Konsumen Daring } \\
\text { e. Valensi Ulasan Konsumen Daring } \\
\text { f. Kelengkapan Ulasan Konsumen } \\
\text { Daring } \\
\text { (Zhao, Xinyuan, Wang, Guo, dan } \\
\text { Law 2015 dalam Karmila, Suharyono, } \\
\text { Nuralam 2019:204) }\end{array}$ \\
\hline 4 & $\begin{array}{l}\text { Keputusan } \\
\text { Pembelian }\end{array}$ & $\begin{array}{l}\text { Keputusan pembelian adalah } \\
\text { aktivitas pembelian suatu merek } \\
\text { tertentu yang diinginkan oleh }\end{array}$ & $\begin{array}{l}\text { Pengenalan Masalah } \\
\text { b. Pencarian Informasi } \\
\text { c. Evaluasi Alternatif }\end{array}$ \\
\hline
\end{tabular}




\begin{tabular}{|l|l|l|}
\hline & konsumen. & $\begin{array}{l}\text { d. Keputusan Pembelian } \\
\text { e. Perilaku Pascapembelian } \\
\text { (Kotler \& Keller (2009:184-190) }\end{array}$ \\
\hline
\end{tabular}

Uji Validitas dan reliabilitas dilakukan untuk pengujian instrumen. Suatu instrumen dikatakan valid jika $\mathrm{r}$ hitung $>\mathrm{r}$ tabel dengan tingkat kepercayaan 95\%. Suatu instrumen dikatakan tidak valid jika $r$ hitung $<\mathrm{r}$ tabel. Nilai Cronbach's Alpha variabel $>0,60$ maka variabel tersebut dinyatakan reliabel. Uji asumsi klasik yang digunakan yaitu uji normalitas, multikolinieritas, heteroskedastisitas. Teknik analisis data yang digunakan pada penelitian ini yaitu teknik analisis regresi linear berganda. Sanusi (2011:134) mendefinisikan analisis regresi linear berganda sebagai suatu teknik analisis hasil perluasan dari regresi linear sederhana karena jumlah variabel bebas lebih dari satu.

Keterangan :

$$
Y=a+b_{1} X_{1}+b_{2} X_{2}+b_{3} X_{3}+e
$$

$\begin{array}{ll}\mathrm{Y} & =\text { Keputusan Pembelian } \\ \mathrm{a} & =\text { Konstanta } \\ b_{1} b_{2} b_{3} b_{k} & =\text { Koefisien Regresi Parsial } \\ X_{1} & =\text { Harga } \\ X_{2} & =\text { Kemudahan Penggunaan } \\ X_{3} & =\text { Ulasan konsumen daring } \\ \mathrm{e} & =\text { error atau sisa }\end{array}$

Uji hipotesis dilakukan dengan Uji $\mathrm{F}$ untuk mengetahui pengaruh secara simultan pada variabel harga, kemudahan penggunaan, dan ulasan konsumen daring terhadap keputusan pembelian serta uji $t$ untuk mengetahui pengaruh secara parsial pada variabel harga, kemudahan penggunaan, dan ulasan konsumen daring terhadap keputusan pembelian. Uji koefisien determinasi dilakukan untuk mengetahui seberapa besar pengaruh variabel bebas (harga, kemudahan penggunaan, dan ulasan konsumen daring) terhadap variabel terikat (keputusan pembelian).

\section{Pembahasan}

Responden telah memenuhi kriteria yang ditentukan sebelumnya. Penelitian ini mendapakan hasil bahwa karakteristik responden yang melakukan pembelian pada marketplace Shopee berdasarkan tingkat usia yaitu usia $<21$ tahun mempunyai persentase sebanyak 20\%, usia 21-30 tahun mempunyai persentase 79\%, dan usia 31-40 tahun mempunyai persentase $1 \%$. Dapat diketahui bahwa sampel pada penelitian ini paling banyak adalah yang berusia 21-30 tahun. Rata-rata variabel harga 4,15 dengan kategori terjangkau menurut responden. Rata-rata variabel kemudahan penggunaan adalah 4,45 masuk kategori sangat baik menurut responden. Rata-rata variabel ulasan konsumen daring adalah 4,44 masuk kategori sangat baik menurut responden. Rata-rata variabel keputusan pembelian adalah 4.07 masuk kategori sangat baik menurut responden.

Uji validitas telah dilakukan dan seluruh item pertanyaan dalam kuesioner memiliki nilai $r$ hitung lebih besar daripada nilai $r$ tabel sehingga semua item pernyataan dinyatakan valid. Berdasarkan uji reliabilitas nilai Cronbach's alpha dari instrumen harga adalah sebesar 0,752, kemudahan penggunaan sebesar 0,898, ulasan konsumen daring sebesar 0,819, dan keputusan pembelian sebesar 0,780. Dapat kita lihat bersama bahwa semua nilai Cronbach's 
alpha dari masing-masing variabel lebih besar (>) daripada 0,60. Maka dapat diambil kesimpulan bahwa semua variabel dikatakan reliabel.

Hasil uji normalitas dihasilkan nilai asymp signifikansi (2-tailed) adalah sebesar 0,812 $>0,05$ sehingga data berdistribusi normal. Nilai VIF masing-masing variabel lebih kecil $(<)$ dari 10. Dapat disimpulkan bahwa model pada penelitian ini tidak terjadi gejala multikolinearitas. Nilai Sig. masing-masing variabel lebih besar (>) dari 0,05, sehingga dapat disimpulkan bahwa model pada penelitian ini tidak terjadi gejala heteroskedastisitas.

Tabel 2 Analisis Regresi Linear Berganda

\begin{tabular}{|l|c|c|c|c|c|}
\hline \multicolumn{1}{|c|}{ Model } & B & $\begin{array}{c}\text { Std. } \\
\text { Error }\end{array}$ & Beta & T & Sig \\
\hline Constant & 0,639 & 2,447 & & 0,261 & 0,794 \\
\hline Harga (X1) & 0,592 & 0,146 & 0,415 & 4,061 & 0,000 \\
\hline Kemudahan penggunaan (X2) & 0,229 & 0,126 & 0,178 & 1,790 & 0,077 \\
\hline Ulasan konsumen daring (X3) & 0,165 & 0,077 & 0,194 & 2,131 & 0,036 \\
\hline
\end{tabular}

Berdasarkan Tabel 2 diperoleh persamaan regresi linear berganda sebagai berikut:

$$
\mathrm{Y}=0,639+0,592 \mathrm{X} 1+0,229 \times 2+0,165 \times 3
$$

Nilai dari persamaan regresi dengan konstanta 0,639 memiliki makna apabila nilai variabel harga, kemudahan penggunaan, dan ulasan konsumen daring dianggap konstan atau bernilai 0 maka konsumen tetap memiliki keputusan pembelian yang positif. Nilai positif pada masing masing koefisien variabel independen menunjukkan hubungan yang searah antara masing masing variabel independen terhadap variabel dependennya. Namun bila meninjau lebih jauh terhadap uji $\mathrm{t}$ (signifikansi pengaruh) pada variabel $\mathrm{X} 2$, yang menunjukkan tidak adanya pengaruh yang signifikan, maka koefisien positif pada variabel kemudahan penggunaan menjadi tidak bermakna. Interpretasi koefisien positif pada X1 dan $\mathrm{X} 3$ adalah apabila konsumen merasa harga produk semakin sesuai dengan keinginannya, dan semakin baik ulasan yang konsumen cermati, maka semakin tertarik pula mereka untuk melakukan transaksi pembelian produk. Nilai Adjusted R Square adalah 0,432 (43,2\%) yang berarti kemampuan variabel harga, kemudahan penggunaan, dan ulasan konsumen daring, dalam menjelaskan varians dari variabel keputusan pembelian adalah sebesar 43,2\%, sedangkan $56.8 \%$ sisanya dipengaruhi oleh variabel independen lain yang tidak diuji dalam penelitian ini. Uji F mendapatkan hasil bahwa nilai $\mathrm{F}$ hitung 26,103 > 2,698 yang berarti harga, kemudahan penggunaan, dan ulasan konsumen daring secara simultan berpengaruh terhadap keputusan pembelian.

Uji t mendapatkan hasil bahwa nilai t hitung variabel harga adalah sebesar 4,061 yang nilainya lebih tinggi dibandingkan dengan t tabel sebesar 1,985, artinya variabel harga secara parsial berpengaruh signifikan terhadap keputusan pembelian. Hasil ini sesuai dengan penelitian dari Istanti (2017) yang mengatakan bahwa variabel harga secara parsial berpengaruh terhadap keputusan pembelian. Harga yang di tawarkan oleh marketplace Shopee relatif terjangkau bagi konsumen karena konsumen dapat memesan produk maupun jasa kepada produsen secara langsung melalui aplikasi Shopee dan karena toko yang ada pada marketplace Shopee tidak perlu membayar sewa gedung sehingga biaya produksi menjadi lebih murah dan membuat harga produk maupun jasa yang ditawarkan relatif terjangkau. Selain itu, harga yang ditawarkan oleh marketplace Shopee sudah sesuai dengan kualitas produk dan jasa yang akan diperoleh. 


\section{Mita, Fransisca Desiana Pranatasari, Kristia}

Uji t pada variabel kemudahan penggunaan mendapatkan hasil nilai t hitung senilai 1,790 yang lebih kecil dibandingkan $t$ tabel senilao 1,985 , artinya variabel kemudahan pengguna secara parsial tidak berpengaruh terhadap keputusan pembelian. Hasil ini selaras dengan penelitian yang dilakukan oleh Fandi et al (2019) yang mengatakan bahwa kemudahan penggunaan secara parsial tidak berpengaruh terhadap keputusan pembelian. Dari hasil wawancara konfirmasi singkat dengan beberapa responden, beberapa menyatakan bahwa kemudahan penggunaan marketplace Shopee dengan platform e-commerce kompetitor lainnya seperti Tokopedia, Zalora, dan Bukalapak tidak memiliki perbedaan yang mencolok, sehingga tidak dapat mempengaruhi keputusan pembelian mereka. Senada dengan pernyataan Dolot (2018) Generasi Z merupakan generasi yang mudah familiar dalam mempelajari mekanisme teknologi bekerja, sehingga kemudahan penggunaan menjadi hal dasar yang dianggap memang seharusnya dimiliki oleh platform dan bisnis teknologi yang beredar di pasar.

Uji t mendapatkan hasil nilai t hitung variabel ulasan konsumen daring adalah sebesar 2,131 yang nilainya lebih besar dibandingkan t tabel 1,985, artinya variabel ulasan konsumen daring secara parsial berpengaruh signifikan terhadap keputusan pembelian. Hal ini berarti semakin baik ulasan konsumen daring pada marketplace Shopee maka konsumen akan semakin pasti untuk melakukan keputusan pembelian. Hasil ini selaras dengan penelitian dari Atsila et al (2017) yang mengatakan bahwa ulasan konsumen daring secara parsial berpengaruh terhadap keputusan pembelian. Ulasan konsumen pada marketplace Shopee sudah terpercaya bagi konsumen karena ulasan konsumen yang berupa peringkat (rating) dan komentar yang diberikan konsumen dapat membantu konsumen untuk menjadi bahan pertimbangan sebelum melakukan keputusan pembelian pada marketplace Shopee. Semakin banyak komentar positif dan semakin tinggi peringkat yang diperoleh suatu produk maupun jasa maka akan semakin menarik minat konsumen untuk melakukan keputusan pembelian pada marketplace Shopee.

\section{Kesimpulan}

Penelitian ini mendapatkan hasil bahwa harga, kemudahan penggunaan, dan ulasan konsumen daring secara simultan berpengaruh terhadap keputusan pembelian pada marketplace Shopee. Harga secara parsial berpengaruh terhadap keputusan pembelian pada marketplace Shopee. Kemudahan penggunaan secara parsial tidak berpengaruh terhadap keputusan pembelian. Ulasan konsumen daring secara parsial berpengaruh terhadap keputusan pembelian.

Saran yang diberikan kepada Shopee terkait harga yaitu tetap menjaga daya saing, keterjangkauan harga, serta manfaat yang akan diperoleh responden. Selain itu, keseluruhan rata-rata indikator harga masuk dalam kategori kategori terjangkau. Marketplace Shopee perlu meyakinkan konsumen bahwa harga produk dan jasa yang ditawarkan pada marketplace Shopee sudah sesuai dengan kualitas produk yang akan diperoleh konsumen. Perusahaan dapat meyakinkan konsumen dengan cara memberi peraturan kepada para penjual supaya menampilkan gambar produk yang sesuai dengan aslinya. Penjual pada aplikasi Shopee diwajibkan untuk memberikan gambar dan keterangan produk yang sesuai dengan aslinya. Karena beberapa penjual menampilkan gambar produk yang sangat bagus namun setelah produk tersebut diterima oleh konsumen, produk tersebut tidak sesuai ekspetasi konsumen. hal tersebut tentu saja akan membuat konsumen kecewa karena produk maupun jasa yang diterima tidak sesuai dengan harga dan ekspetasi konsumen. Perusahaan diharapkan dapat memberikan sanksi yang tegas untuk para penjual yang tidak jujur agar konsumen tidak kecewa, karena hal ini akan sangat berdampak untuk kelangsungan hidup perusahaan. 
Saran yang diberikan kepada Shopee terkait ulasan konsumen daring sebaiknya perusahaan melakukan kerjasama dengan para Youtuber terkenal yang memiliki citra baik di mata konsumen untuk menarik konsumen melakukan pembelian pada marketplace Shopee. Dengan adanya influencer yang dapat membantu konsumen dalam melakukan keputusan pembelian, diharapkan upaya ini dapat menjadi hal baik untuk kelangsungan hidup perusahaan.

\section{Daftar Pustaka}

Anwar, Sanusi. 2011. Metodologi Penelitian Bisnis. Jakarta: Salemba Empat

Atsila, Riris Eka., Siti Saroh \& Dadang Krisdianto 2020. "Pengaruh Electronic Word Of Mouth, Online Consumer Review, dan Integrated Marketing Communication Di Media Sosial Terhadap Keputusan Pembelian," Jurnal. Jurusan Administrasi Bisnis, Fakultas Ilmu Administrasi, Universitas Islam Malang, 9 (1), 35-42.

Davis, F.D. 1989. "Perceived Usefulness, Perceived Ease of Use, and User Acceptance of Information Technology," Mis Quarterly (13:3),1989.

Dolot, A. (2018). New Trends In Management The Characteristics Of Generation Z. EMentor, 2(2), 44-50. https://doi.org/http://dx.doi. org/10.15219/em74.1351

Fatihudin, Didin \& Anang Firmansyah. 2019. Pemasaran Jasa. Yogyakarta: Deepublish.

Febriana, Mitha. \& Edy Yulianto. 2018. "Pengaruh Online Cunsumer Review Oleh Beauty Vlogger Terhadap Keputusan Pembelian (Survei Pada Mahasiswa Fakultas Ilmu Administrasi Universitas Brawijaya Angkatan 2014/2015 dan 2015/2016 Yang Membeli Dan Menggunakan Purbasari Matte Lipstik)," Jurnal Fakultas Ilmu Administrasi Universitas Brawijaya Malang. 58 (1), 1-9.

Iprice.co.id.2020.“PetaE-CommerceIndonesia"https://iprice.co.id/insights/mapofecommerce/. Diakses tanggal 27 Oktober 2020.

Istanti, Fredianaika. 2017. "Pengaruh Harga, Kepercayaan, Kemudahan Berbelanja Dan EPromosi Terhadap Keputusan Pembelian Belanja Online Di Kota Surabaya," Jurnal Administrasi Bisnis Politeknik NSC, Surabaya, 4 (1), 1-9.

Jogiyanto. 2007. Sistem Informasi Keprilakuan. Yogyakarta: Penerbit Andi.

Kotler, Philip. \& Keller Kevin Lane. 2009. (terj. Bob Sabran, MM). Manajemen Pemasaran, Edisi 13. Jakarta: Erlangga.

Muchammad Sukron, Roni Ady. 2019. "Pengaruh Kemudahan Penggunaan, Islamic Branding dan E-Service Quality Terhadap Keputusan Pembelian di Tokopedia Dengan Minat Beli Sebagai Variabel Intervening," Skripsi. Institut Agama Islam Negeri, Salatiga.

Noor, Juliansyah. 2014. Metodologi Penelitian. Jakarta: Kencana.

Rangkuti, Freddy. 2013. Riset Pemasaran. Jakarta: PT Gramedia Pustaka Utama.

Rosdiana, Eva., Hadi Suharno \& Umi Kulsum 2020. "Pengaruh Harga, Keanekaragaman Produk, dan Minat Beli Terhadap Keputusan Pembelian Pada Toko Online Shopee," Jurnal Fakultas Ekonomi dan Bisnis, Universitas Islam Syekh-Yusuf Tangerang, 24 (2), 1-11.

Sarjono, Haryadi \& Julianita Winda. 2011. SPSS vs LISREL Sebuah Pengantar Aplikasi Untuk Riset. Jakarta: Salemba Empat.

Tasya Kamila, Korina., Suharyono \& Inggang Perwangsa Nuralam. 2019. "Pengaruh Online Consumer Review Terhadap Keputusan Pembelian," Jurnal Fakultas Ilmu Administrasi Universitas Brawijaya Malang. 72 (1), 1-10.

Tjiptono, Fandy. 2019. Strategi Pemasaran. Yogyakarta: ANDI. 
Wahyuningtyas, Y. F \& Dyah Ayu Widiastuti. 2015. “Analisis Pengaruh Persepsi Risiko, Kemudahan dan Manfaat Terhadap Keputusan Pembelian Secara Online (Studi Kasus Pada Konsumen Barang Fashion di Facebook),"Journal Kajian Bisnis, 23(2), 112120.

We are social \& Hootsuite. 2019. Digital 2019: Indonesia-DataRepotal-Global Digital Insights. DataReportal, 77. https://datareportal.com/reports/digital-2019-indonesia. 2019. Digital 2019. We Are Social \& Hootsuite, 76.

2020. Digital 2020: Indonesia-DataRepotal-Global Digital Insights.

DataReportal, 92. https://datareportal.com/reports/digital-2020-indonesia.

Wiyono, Gendro. 2011. Merancang Penelitian Bisnis dengan Alat Analisis SPSS 17.0 \&Smart PLS 2.0. Yogyakarta: STIM YKPN.

Yusup, Muhamad. 2011.“Analisis Pengaruh Promosi, Harga, Kualitas Produk Dan Layanan Purna Jual Terhadap Keputusan Pembelian Sepeda Motor Honda,(Studi Kasus pada Mahasiswa Fakultas Ekonomi Universitas Diponegoro..Semarang),"Skripsi.Universitas..Diponegoro 